\section{Bojan Žnidaršič}

Vitra Cerknica

\title{
NACIONALNA ENERGETSKA POT SLOVENIJA KOT INTERAKTIVNA METODA UČENJA
}

\section{POVZETEK}

Avtor predstavlja inovacijo v neformalnem izobraževanju odraslih na področju učinkovite rabe energije (URE) in obnovljivih virov energije (OVE). To je Nacionalna energetska pot Slovenija, ki z različnimi viri informacij sledi sodobnim spoznanjem o učenju odraslih, kar omogoča postopno in individualizirano konstruiranje znanja ter na podlagi tega informirano odločanje. Na spletnem portalu so predstavljeni različni nasveti in mreža 660 raznolikih stavb iz vse Slovenije. To so primeri dobrih praks, ki jih lahko iskalci informacij tudi obiščejo in se pogovorijo z lastniki. Slednji delujejo kot mreža izkušenih prostovoljcev, ki svoja spoznanja in izkušnje prenašajo novim graditeljem ali investitorjem. Pri tovrstnem izobraževanju, ki je namenjeno kakovostni izbiri energetsko učinkovitih materialov in opreme, se združuje v celoto strokovno, nekomercialno in brezplačno svetovanje ter izkustveno znanje lastnikov ali upravljavcev energetsko učinkovitih objektov.

Ključne besede: učenje odraslih, vseživljenjsko učenje, izkustveno učenje, neformalno izobraževanje odraslih, učinkovita raba energije, obnovljivi viri, interaktivno učenje, prostovoljstvo, kakovost življenja, energetsko svetovanje

\section{NATIONAL ENERGY PATH SLOVENIA AS AN INTERACTIVE LEARNING METHOD - ABSTRACT}

The paper presents an innovation in the field of non-formal adult education for efficient energy (EE) and renewable energy sources (RES). It is called Nacionalna energetska pot Slovenija - National Energy Path Slovenia, which follows the modern trends of adult education and learning by using different sources of information. This in turn enables gradual and individualized knowledge construction and, consequently, better informed decision making. The NEP web page displays different suggestions and a network of 660 diverse buildings that use energy efficient equipment. These serve as examples of good practice that learners can visit and explore, while also talking with their owners. The owners act as a network of experienced volunteers that pass on their knowledge and experience to new builders or investors. This kind of education process, the goal of which is a better decision-making process when choosing energy efficient equipment and materials, merges professional, non-commercial and free advice with personal experience and knowledge of the owners or managers of energy efficient buildings.

Keywords: adult education, lifelong learning, efficient energy, renewable energy sources, experiential learning, nonformal learning of adults, interactive learning, volunteering, information for decision support, quality of life, energy consulting

UDK: $374.7: 66.012 .3$

DOI: http://dx.doi.org/10.4312/as.19.4.82-89

\section{UVOD}

Čar vseživljenjskega učenja ali učenja v odraslosti je prosta izbira področja in poti do cilja. Učenje je lahko namenjeno osebnemu razvoju, večji konkurenčnosti na trgu dela ter osebni ali javni koristi. Motivi za učenje so različni. Pri rabi energije je verjetno najpomembnejši vzgib za učenje $\mathrm{v}$ zniževanju stroškov za ogrevanje prostorov in sanitarne vode. Brez dvoma lahko ob tem v ospredje postavimo še večjo kakovost življenja in manjše obremenjevanje okolja, kar je del strategij učinkovite rabe energije (prim. Drugi nacionalni akcijski načrt za energetsko 
učinkovitost 2011-2016). Naslednje vprašanje je, kako naj bi se odrasli učili o uporabi energije. Načini morajo biti prilagojeni potrebam odraslih in njihovemu dostopanju do informacij. Praktične izkušnje gospodarjenja $z$ energijo 660 lastnikov zasebnih stavb ali upravnikov javnih stavb, ki so vključeni v projekt Nacionalna energetska pot Slovenija, nam lahko pomagajo pri odločanju. Vsi so prostovoljci, ki so pripravljeni predstaviti dobre ali slabe plati posameznih energetskih ukrepov, predvsem pa odpreti vrata stavb, kjer si lahko zainteresirani ogledajo različne rešitve. Izkustveno učenje in prenos izkustvenega znanja zmanjšuje možnost ponavljanja napak, ki so običajno povezane $\mathrm{s}$ težavami bivanja in visokimi stroški obratovanja stavbe.

Živimo v času, ko se gradnja družinskih, javnih in poslovnih stavb silovito spreminja. Vedno dražja energija in zahteve za varovanje okolja se preslikavajo v vedno strožje lokacijske, gradbene, instalacijske, vzdrževalne in obratovalne standarde. Današnja novogradnja je v vseh pogledih drugačna od gradnje pred desetletjem ali več. To so razlogi, da investitor (pre)pogosto nima uporabnih informacij, ne ve, kam naj se obrne po pomoč, kdo je odgovoren, kdo pristojen, kdo bi moral kaj narediti. Zaradi pomanjkanja informacij se pogosto odloča na podlagi vprašljivih nasvetov sorodnikov, prijateljev, izvajalcev ali trgovcev, ki imajo lahko pri nasvetu komercialne interese. Da bi bilo odločanje lažje in predvsem bolj informirano, smo zasnovali projekt Nacionalna energetska pot Slovenija ali krajše NEP Slovenija (glej http://nep.vitra.si), kjer lahko vsak investitor poišče verodostojne, nekomercialne in uporabne informacije za dva ključna segmenta vsake stavbe. To sta toplotni ovoj ter ogrevanje prostorov in sanitarne vode.

V članku bo predstavljen projekt NEP Slovenija, ki se razvija po dveh načelih: a) le zanesljiva informacija je pravi ključ za kakovostno odločanje in

b) informacije so oblikovane tako, da se prilagodijo potrebam odraslih.

NEP Slovenija je slovenska inovacija na področju neformalnega izobraževanja odraslih. Vključuje spletni portal, mrežo vzorčnih objektov, ki so kot izložbeno okno dobrih praks, ter možnost pogovora $\mathrm{z}$ lastniki na objektih samih.

\section{KAKOVOSTNE INFORMACIJE KOT VIR ODLOČANIA}

Zamislimo si stresne situacije pred gradnjo ali obnovo družinske hiše. Običajno se za tak podvig odloča mlad par brez življenjskih izkušenj. O njuni nesposobnosti so prepričani starši, ki poskušajo - skupaj z denarno pomočjo in dobrimi nameni - vsiliti pogosto zastarele rešitve. Par nima splošnega gradbenega in energetskega znanja, ne pozna postopkov in časovnih zaporedij gradnje. Ne pozna projektantov in izvajalcev, z njimi ne sklepa pogodb, ne upa jih vprašati za stroške, načine plačila ipd. Na forumih bere kontradiktorne izkušnje, za katere ne ve, ali so prave, ali jih piše ponudnik ali konkurenca. Zaveda se, da bo hiša postavljena za dolgo časa, zato želi čim nižji strošek investicije za čim večje ugodje bivanja in čim nižje stroške energije za delovanje. Posebno področje so izvajalci. $\mathrm{Na}$ začetku gradnje je marsikdo prepričan, da poznajo svoj posel, med gradnjo je vedno znova razočaran. Ko ob slabih izvedbah ugotovi njihovo šibko strokovnost, je (prepozno) jezen sam nase, ker pred odločitvijo ni preveril njihove kakovosti dela.

Odločitev je vedno težka, saj ne vemo, kako resnično deluje zamišljena investicija v realni situaciji, prav tako nimamo zanesljivih 
informacij. Odgovore si v prvem koraku poiščemo pri energetskih svetovalcih, ki delujejo v mreži ENSVET, v drugem pa na portalu NEP Slovenija. Za tako imenovano informirano odločanje - odločati pa se mora vedno le investitor - manjkata najpogosteje dve bistveni informaciji, in sicer (a) kje videti svojo investicijo v podobni realni situaciji in (b) kje pridobiti uporabniške izkušnje iz prve roke, torej od nekoga, ki je podobno investicijo že uresničil.

Omenjene dileme pri odločanju, izvedbi in nadzoru se pojavljajo povsod in na vseh ravneh. Tudi župani, direktorji ali predsedniki združenj morajo prepričljivo utemeljiti svoje odločitve. Zakaj je lesen vrtec boljši od zidanega, sekanci primernejši kot peleti, daljinsko ogrevanje sprejemljivejše od lokalnega, oddaja strehe v najem boljša od lastne investicije v sončno elektrarno, mehansko prezračevanje z rekuperacijo boljše od prezračevanja skozi okna so vprašanja, na katera si posamezniki ne znajo odgovoriti brez strokovnega znanja.

V postopku izdelave načrta za novogradnjo ali obnovo se moramo odločati o veliko elementih. Odločanje bo lažje in zanesljivejše, če bo izhajalo iz strokovnih in nekomercialnih informacij. V nasprotnem primeru bomo lahko, na primer, v neizolirani stavbi s talnim gretjem na toplotno črpalko zmrzovali (ali pa bankrotirali), v pasivni hiši nam bo hitro prevroče. Rekuperacija zraka v stavbi s slabimi okni je nepotreben strošek, v pasivni hiši pa nuja in dopolnilni ogrevalni sistem. Dimniška cev premera 20 centimetrov je neprimerna za plinski kondenzacijski kotel, prava pa za kamin na polena. Neizoliran temelj pritličnega stanovanja bo izvor plesni, v neogrevani kleti pa le povzročitelj »lepotnih« peg na notranjem ometu. Za ogrevanje 100 kvadratnih metrov »klasične « hiše potrebujemo 1.500 litrov kurilnega olja, enako velika pasivna hiša se vse leto ogreva s 150 litri, ničenergijska hiša pa vso potrebno energijo proizvede sama. Hidravlično uravnoteženje ogrevalnega sistema je $\mathrm{v}$ blokih nuja, v družinskih hišah je nepotrebno. Ročna ali polavtomatska regulacija zadostuje za »navadno « hišo, pametna instalacija pa edina omogoča delovanje skoraj ničenergijske hiše, ki se gradi danes. Premišljeno postavljen napušč strehe je optimalno okensko senčilo za vse čase, odpiranje stavbe na jug nam tudi pozimi brezplačno (do)greva stavbo. $\mathrm{V}$ tovarni narejeno hišo kupimo kot končni izdelek, zidana $\mathrm{z}$ domačimi »mojstri« nam težave pokaže takoj po vselitvi. Vsi ti primeri kažejo, da nam znanje in nekomercialno svetovanje - ne denar - omogočita učinkovito odločanje in s tem rabo energije, nizke stroške, visoko stopnjo bivalnega ugodja ter manjše obremenjevanje okolja.

\section{KOMPLEKSNOST UČENIA}

Učenje je kompleksen proces, ki zajema vse ravni človekove osebnosti in vse vrste človekove inteligentnosti (prim. Gardner, 2010; Rose \& Goll, 1993). Tehnike podajanja znanj se nenehno spreminjajo ter prilagajajo potrebam in značilnostim odraslih. Od posnemanja rokodelskih spretnosti med mojstrom in vajencem do brezosebnega učenja, ki ga omogoča informacijsko-komunikacijska tehnologija, obstaja velik razpon metod in strategij. Razvoj orodij nove tehnologije je sprožil silovit razcvet formalnega ali neformalnega učenja. Večsmerni pretok informacij in znanja - predvsem pa izjemno veliko neodvisnih virov - odpravlja vlogi vsevednega učitelja kot nosilca znanja in nevednega učenca. Vseživljenjsko učenje je postalo pravilo in geslo »Each one teach one « (vsakdo se uči in uči vsakogar) ponazarja demokracijo, ki jo procesu učenja omogoča med drugim tudi e-tehnologija. Tisti, ki se želi učiti, si lahko sam izbira vire, stopnjo težavnosti 
in globino spoznavanja. Wikipedija je primer globalne baze znanj anonimnih avtorjev, njen hitri razcvet pa potrditev uporabnosti spleta kot vira učenja.

Med domačimi pristopi je tudi portal NEP Slovenija, ki je poseben v tem, da omogoča in spodbuja pridobivanje znanja na več ravneh. Učenje naj bi vključevalo kognitivno (spoznavno), afektivno (čustveno) in psihomotorično (spretnostno) aktivnost. Za kognitivno spoznavanje zadostuje prebiranje popisnih listov, na katerih je celovito predstavljeno 660 stavb iz vse Slovenije. Učenje poteka prek zbiranja informacij na spletni strani in popisnih listih vseh 660 stavb. Temu (lahko) sledi ogled objektov in situ ter pogovor z lastniki, ki pomeni okolje za dialoško učenje, čustveno doživljanje sogovornika in izkušenj. Poleg tega prepleta (kognitivno, čustveno in spretnostno) je NEP Slovenija tudi inovativen preplet prenosa strokovnega znanja (svetovalcev in oblikovalcev nasvetov na spletni strani) in izkustvenega znanja investitorjev (lastnikov objektov).

\section{RAZLIČNE POTI VSTOPANIA INFORMACI]}

Kompleksnost učenja je povezana z različnimi čutili, prek katerih vstopajo informacije. Procesi razumevanja in posredovanja sporočil potekajo pri vsakem posamezniku drugače, odvisno od razvitosti posameznik čutov. Novo sporočilo pride $\mathrm{v}$ možgane prek enega ali več čutov. Sporočilo lahko vidimo, slišimo, se ga dotaknemo, ga zavohamo ali okusimo. Celotno čutno področje razdelimo na zunanji (eksterni) in notranji (interni) del. K zunanjim uvrščamo Vizualni (vid), Avditivni (sluh), Kinestetični (dotik), Olfaktorni (vonj) in Gustatorni (okus) čut, kar označimo s kratico VAKOG (prim. NLP Representational Systems). Za notranje čute nimamo posebnih poimenovanj. Intuicija je splošen izraz. Poimenujemo jih tudi notranji glas, notranje uho ali notranje predstave občutkov in razpoloženj.

Ljudje se zelo razlikujemo po tem, kako najlaže osvojimo novo sporočilo. Danes se veliko ljudi uči predvsem na podlagi vidnih sporočil, kot so slike, grafi, tabele, skice, video, film ipd. Tisti, ki imajo najbolj razvit slušni kanal, se največ naučijo na predavanjih ali ob poslušanju medijev, npr. radia ali predavatelja. Nasprotno od njih sprejemajo informacije kinestetiki, ki jim je sedenje in poslušanje muka. Potrebujejo gibanje, saj se učijo s čustveno gibalno metodo. Zanje so pomembni lastni zapiski, demonstracije, vaje, delo v skupinah, dotiki in gibanje. Okus in vonj sta danes $\mathrm{v}$ izobraževanju manj pomembna, razen za specifične poklice.

Portal NEP Slovenija zadovolji vse tri najpomembnejše čute. Vizualnega podpira obilica slikovnega gradiva, s katerim dobijo besedni opisi v člankih ter dobrih in slabih praksah večjo razumljivost in zapomljivost. Slušnemu in vidnemu kanalu je namenjeno 20 videoposnetkov dobre prakse. Vizualni tipi bodo gledali video in brali

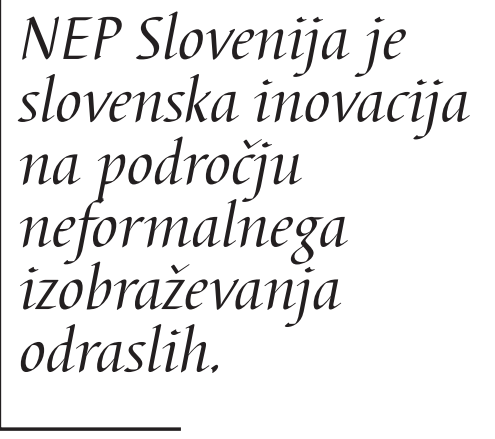
podnapise, avditivnim bo zadostovalo poslušanje strokovne razlage. Kinestetiki se bodo najbolje počutili med obiskom stavbe na terenu. Tam bodo lahko preverili gladkost ometov, občutili toploto ogrevalnega sistema, začutili toploto zimskega vrta ali prijeli suhe sekance. Ogled stavbe omogoča celovito razumevanje s pomočjo vseh petih čutil - pa naj bo to sprehod po stavbi, poslušanje izkušenj gostitelja, zvok trkanja po toplotni izolaciji fasade, vonjave polen ali sekancev. Za zadovoljitev okusov pa običajno poskrbi gostitelj s polno mizo. 
Med uspešne oblike prenosa znanj in informacij sodijo tiste, ki vključujejo čim več kanalov VAKOG. S tem se prenos znanja najbolj približa naravnim sposobnostim dojemanja vsakega posameznika. Trditev potrjujejo raziskave, ki smo jih povzeli po Townsendu (1998: 70). Te navajajo, da si v povprečju zapomnimo: 10 odstotkov tistega, kar preberemo; 20 odstotkov tistega, kar slišimo; 30 odstotkov tistega, kar vidimo; 50 odstotkov tistega, kar vidimo in slišimo; 80 odstotkov tistega, kar rečemo; 90 odstotkov tistega, kar rečemo in naredimo. Pri učenju je torej pomembna dejavnost, kar poudarja tudi metoda akcijskega učenja (prim. Pedler \& Abbott, 2013).

V vsakem učnem procesu je najpomembnejša usklajenost (kalibracija) med učiteljem, ki posreduje (oddaja) informacije, in učencem, ki jih sprejema. Usklajenost mora biti dvosmerna, saj znajo učenci postaviti »neugodna « vprašanja ali razviti svoj pristop ali idejo. Klimaks uspešnosti dosežemo takrat, ko začnejo udeleženci v skupini odpirati vprašanja, nanje pa - na podlagi znanja in izkušenj - odgovarjajo drugi udeleženci. Te situacije imenujemo sodelovalno učenje (prim. Peklaj, 2001; Vella, 2008). V takih trenutkih je predavatelj bolj moderator, takrat se tudi najbolje pokaže, kako se lahko vsak uči od vsakega. Skladno s sodobnimi ugotovitvami o učenju in hitrim razvojem tehnologije nastajajo nove metode dela pri izobraževanju in svetovanju. Drugačni so pristopi in tehnike podajanja znanja, drugačno je evalviranje učnega procesa.

\section{ENERGETSKO IZOBRAŽEVANJE IN SVETOVANJE}

Formalno izobraževanje nam da - ne glede na stopnjo in smer izobraževanja - le osnovo. Odpre nam vrata in omogoči, da začnemo osebnostno, socialno in poslovno delo- vati. Nenehen razvoj pa nam lahko omogoči le učenje, ki traja tudi v odraslosti, saj šele v praksi vidimo, kje smo močni (izobrazbeno in osebnostno) in kje šibki, predvsem pa, katera so tista področja, kjer potrebujemo novo znanje. Eno izmed aktualnih področij, ki se dotika vsakega posameznika, je energija $\mathrm{v}$ gospodinjstvu, natančneje njena učinkovita raba, ter uporaba obnovljivih virov. Gospodinjstvom so na voljo brezplačna energetska svetovanja ENSVET po vsej Sloveniji (glej http://gcs.gi-zrmk.si/Svetovanje/index-pisarne.html), portal NEP Slovenija (glej http:// nep.vitra.si) in socialno omrežje Facebook (glej https://www.facebook.com/NEP.Slovenija). Korist pridobljenega znanja je takoj opazna pri nižjih stroških gospodinjstva in manjšem obremenjevanju okolja.

V nadaljevanju bo predstavljeno, kako lahko povezujemo svetovanje in uporabo portala NEP Slovenija v praksi. V Cerknici delujem kot energetski svetovalec ENSVET od leta 1994. Kot sem zapisal zgoraj, je vizualni kanal sprejemanja informacij zelo pomemben (prim. tudi Norris, 2003, str. 98), zato prakticiram svetovanje ob fotografijah. Za pomoč hitremu informiranju svetovalca prinese vsak svetovanec na ključku okrog 50 fotografij objekta, ki bo predmet svetovanja. V nekaj minutah spoznam stavbo zunaj in znotraj ter vse probleme, ki jih je treba pri svetovanju upoštevati. Potem se začne svetovanje ob fotografijah hiše, ki jih ilustriram s primeri s portala NEP Slovenija. Običajno dobijo svetovanci ob predhodnem dogovoru za termin svetovanja »domačo nalogo«. Predvsem so to priporočila za prebiranje tematskih člankov in analiza napak, ki so zajete v rubriki Črna točka (glej http://nep.vitra.si/?crna=1) in Energetski kiksi (glej http://nep.vitra.si/?kiksi=1). Domače priprave so namenjene osredotočenju na problem. Tako se lahko med svetovanjem posvetimo le reševanju konkretne težave. 
Praksa kaže, da so slabi in napačni primeri za učenje dobri primeri, saj se da ob njih razložiti posledice. Običajno so to plesen in visoki stroški energije za ogrevanje prostorov.

\section{ZAMISEL IN ZNAČILNOSTI NACIONALNE ENERGETSKE POTI SLOVENIJA}

Portal Nacionalna energetska pot Slovenija je bil postavljen $\mathrm{v}$ aprilu 2009. Uporabnost $\mathrm{v}$ teh skoraj petih letih potrjuje čez 200 tisoč obiskov in skoraj dva milijona klikov. Razlog, da ima portal $\mathrm{v}$ zadnjem obdobju vsak dan več kot 200 obiskov, si razlagamo s tem, da nam energija kroji življenje, saj se odvisnost od nje vztrajno povečuje. Bolj ko jo spoznavamo, lažje jo obvladujemo; s povečevanjem učinkovitosti rabe energije se znižujejo stroški in zmanjšuje obremenjevanje okolja. Projekt NEP Slovenija se bo nadaljeval doma in v tujini, čeprav smo konec avgusta 2013 projekt, ki je bil podprt z donacijo Švice v okviru Švicarskega prispevka razširjeni Evropski uniji, v tej obliki končali.

Portal je vsebinsko in oblikovno obnovljen, vpeljali smo veliko novih rubrik in predstavili 660 stavb iz vse Slovenije. Od leta 2009 je postal tako kompleksen, da smo naredili grafični in videovodnik po njem. Oba predstavita vse ravni in rubrike portala. Tako so na pregleden način prikazane poti do dobrih ukrepov energetske prakse. Vsaka stavba je celovito predstavljena na svojem popisnem listu. Za vse uporabnike so na voljo tri ravni poglobljenega spoznavanja. Na prvi ravni so to fotografije in besedilo, na drugi telefonski pogovor z lastnikom, na tretji pa obisk stavbe, pogovor z lastnikom in ogled dobrih primerov v praksi. Lastniki - vsi so prostovoljci - imajo izkušnje z delovanjem posameznih naprav ali rešitev v praksi, te so pripravljeni posredovati naprej. To je primer skrbnosti in sodelovalnega učenja $v$ skupnosti ter dejavnega državljanstva. Posamezniki so pripravljeni (brez plačila) odpreti svoje stavbe in pripovedovati o svojih izkušnjah in spoznanjih, da bi se drugi ljudje kakovostno odločali o strategijah za učinkovito rabo energije v svojih stavbah.

Glavna vodila pri zasnovi NEP so bila: jasnost, enostavnost, preglednost in uporabnost ter popolnoma odprt javni dostop na internetu. Zato je bil jasen tudi cilj: vzpostaviti javno dostopen nabor raznolikih primerov dobre energetske prakse ter bivanjske kulture $\mathrm{v}$ individualnih in skupinskih stanovanjih ter poslovnih, proizvodnih in javnih objektih na območju Slovenije, ki jih je s pomočjo štirih iskalnikov enostavno poiskati, obiskati in pridobiti izkušnje uporabnikov. Vsem investitorjem je omogočeno, da predvidene naložbe $\mathrm{v}$ ukrepe učinkovite rabe energije (URE) in obnovljive vire energije (OVE) vidijo v realni situaciji. Pohvale ali kritike posameznih izvajalcev, postopkov ali tehnologij pa izvedo iz prve roke.

Razlogov za pripravo NEP je več. Vsekakor je energija predraga, da bi jo zaradi nevednosti metali skozi okno in po nepotrebnem obremenjevali okolje, zdravje in denarnico. Ideja se je razvila kot nadgradnja in izboljšava učinkov energetskega svetovanja $\mathrm{v}$ zaključnem delu, ko je treba nasvete »preliti« v fasado, okno ali kotlovnico. Ljudje potrebujejo konkreten primer, ob katerem lahko nasvet premislijo in nato svoj projekt uresničijo. Na portalu predstavljamo dobre primere $\mathrm{v}$ družinskih hišah, javnih stavbah, poslovnih objektih, blokih. Zato je namenjen vsem, ki se odločajo za investiranje v URE in OVE. Poleg odraslih, ki so investitorji, so uporaben učni pripomoček dobili tudi učenci, dijaki in študentje. Izvajalci (projektanti, monterji, gradbeniki ...) pa si z ogledi dobrih praks osvežijo znanja in pogledajo $\mathrm{v}$ 
delo konkurence. NEP Slovenija je torej vir za skupnostno učenje, individualno informirano odločanje kot tudi didaktični pripomoček v formalnem izobraževanju in vir za nadaljnje strokovno učenje.

\section{PODROČIA, KI SO DEL VSEBIN NA NEP SLOVENIJA}

Lastniki 660 energetsko učinkovitih stavb omogočajo brezplačen ogled ter uporabniške izkušnje o dobrih in slabih straneh ukrepov, ki jih zajamemo v štiri skupine. Pri vsaki bomo našteli najpogostejše teme.

\section{Obnovljivi viri energije (OVE)}

Toplotna črpalka za ogrevanje sanitarne vode in prostorov (geovrtina, zemeljski kolektor, podtalnica, površinska voda, zrak); lesna biomasa (polena, sekanci, pelete); pasivna in aktivna izraba sonca za ogrevanje prostorov in sanitarne vode (ploščati in vakuumski sprejemniki sončne energije); fotovoltaika (proizvodnja elektrike); bioplin, male hidroelektrarne, vetrne elektrarne, pasivno sončno ogrevanje.

\section{Učinkovita raba energije (URE)}

Kakovostna toplotna izolacija oboda stavbe (tlak, fasada, zadnja plošča, streha); kakovostna vgradnja oken; prezračevana in zelena fasada; nizkotemperaturno (talno, stensko ali stropno) ogrevanje; učinkovita avtomatika (pametna hiša); učinkovita senčila (zunanje rolete, polkna); kondenzacijski kotel na plin ali nafto; kogeneracija (soproizvodnja toplote in elektrike) na različne energente; rekuperacija (vračanje odpadne toplote) zraka in vode, merjenje porabe

\section{Gradnja}

Pasivna in nizkoenergijska hiša; lesena, montažna, masivna hiša; hiša iz slame, hiša iz izolacijskih zidakov, temelnja plošča, obnovljena starejša hiša, zelena streha.

\section{Drugo}

Energetsko knjigovodstvo, delitev stroškov ogrevanja v večstanovanjskih objektih; energetska izkaznica objekta; uporaba deževnice; čiščenje odpadnih in fekalnih voda (rastlinske in mehanske čistilne naprave).

\section{PRIMERI DOBRIH PRAKS IN NAPAK V RAZLIČNIH RUBRIKAH}

Največ se lahko naučimo iz slabih primerov, zato jih obdelujemo $\mathrm{v}$ različnih rubrikah, najbolj celovito in poglobljeno $\mathrm{v}$ člankih. Teh je zdaj 76, vsak mesec dodamo novega. V rubriki Črna točka s fotografijami in komentarji celovito obdelamo en - razmeroma ozek - problem, za katerega nakažemo več rešitev. Najbolj osredotočeni pa so Energetski kiksi, kjer z eno fotografijo, opisom težave in predstavljeno rešitvijo obdelamo eno napako. Objavljenih je čez $100 » k i k s o v \ll$. Žal nam materiala za to rubriko še ne bo zmanjkalo. Dobrim praksam in kakovostnim izvedbam pa je namenjenih 20 videoposnetkov, vsak je dolg štiri do sedem minut, vsi imajo slovenske in angleške podnapise. Namenjamo jih uporabnikom koristili bodo tudi izvajalcem - kot primere kakovostnih energetskih rešitev. Dostopni so na http://www.youtube.com/user/NepSlovenija. Dejavni smo tudi na Facebooku, kjer na https://www.facebook.com/NEP. Slovenija vsak dan predstavimo dobro ali slabo energetsko prakso. 


\section{OBISKI OBJEKTOV, VKLJUČENIH V NEP}

Izobraževanju in lažjemu odločanju so namenjeni tudi obiski posameznih točk NEP Slovenija. Ti so lahko individualni ali skupinski. Za oglede se lahko dogovarja vsak posameznik ali pa jih pripravimo na Vitri. Posamezne točke lahko tudi povežemo $\mathrm{v}$ tematsko pot (biomasa, SSE, energetsko učinkovita novogradnja, prenova ...). Če gre za organizirane skupine (šole, instalaterji, arhitekti, projektanti ipd.), bo Vitra organizirala najboljšo pot, prilagojeno zanimanjem skupine. Tako bo $\mathrm{v}$ poplavi komercialnih nasvetov lažje ločiti zanesljive strokovne informacije in izkustvena spoznanja (uporabno znanje) od prikritih reklam, ki so pri rabi energije postale množične.

\section{SKLEP}

NEP Slovenija se v praksi kaže kot učinkovita strategija učenja odraslih, ki je umeščeno v sodobno družbeno in gospodarsko okolje. S podporo portala NEP Slovenija sledimo načelom trajnostnega razvoja in še posebej eni od definicij, po kateri »trajnostni razvoj pomeni, da namesto omejenih naravnih dobrin izkoriščamo neomejene zmogljivosti našega razuma«, če se izrazim z besedami finskega politika Juha Sipilä.

V življenju moramo sprejeti vrsto odločitev, od manj pomembnih do strateških. Posledice odločitev pri bivalnih, delovnih ali poslovnih stavbah nas spremljajo zelo dolgo, lahko vse življenje. Zamislimo si rezultate slabih odločitev pri dilemah, kot so: zgraditi pasivno ali »navadno《 hišo, prihranke vložiti v fotovoltaiko ali vrednostne papirje, se bomo plesni izognili s prezračevanjem ali bo potrebna temeljita sanacija. Odločitev je vedno težka, zato je smiselno preveriti, kako deluje zamišljena investicija v realni situaciji. S pomočjo zanesljivih informacij uporabnikov, ki imajo izkušnje, bodo odločitve lažje, rezultati pa boljši.

\section{LITERATURA IN VIRI}

Drugi nacionalni akcijski načrt za energetsko učinkovitost za obdobje 2011-2016. Dostopno na: www.energetika-portal.si/dokumenti/strateski-razvojni-dokumenti/akcijski-nacrt-za-energetsko-ucinkovitost (7. 11. 2013).

Gardner, H. (2010). Razsežnost uma. Ljubljana: Tangram.

Energetsko svetovanje za občane ENSVET. Dostopno na: http://gcs.gi-zrmk.si/Svetovanje/index-projekt.html (30. 10. 2013).

Nacionalna energetska pot NEP Slovenija. Dostopno na: http://nep.vitra.si (30. 10. 2013).

NEP https://www.facebook.com/NEP.Slovenija NLP Representational Systems/NLP Modalities.

Dostopno na: www.johnplestertraining.co.uk/ nlp-research-centre/nlp-representational-systems. html (7. 11. 2013).

Norris, J. A. (2003). From Telling to Teaching: A

Dialogue Approach to Adult Learning. North Myrtle Beach: Learning by Dialogue.

Peklaj, C. (2001). Sodelovalno učenje. Ljubljana: DZS.

Peddler, M.; Abbott, C. (2013). Facilitating Action Learning. New York: Open University Press.

Rose, C.; Goll, L. (1993). Umetnost učenja. Ljubljana: Tangram.

Townsend, R. (1998). Bogastvo učenja: umetnost ljubezni do učenja. Ljubljana: Lisac \& Lisac.

Vella, J. (2008). On Teaching and Learning: Putting the Principles and Practices of Dialogue Education into Action. San Francisco: Jossey-Bass. 